\title{
Interdependency Between Demographics and the Construction of Housing as a Pivotal Factor of Society's Sustainable Growth
}

\author{
A. N. Asaul ${ }^{1, *}$, A. B. Assylbayev ${ }^{2}$, K. N. Niiazalieva ${ }^{2}$, M. A. Asaul1, E. D. \\ Trushkovskaya $^{1}$ \\ ${ }^{1}$ Saint Petersburg State University of Architecture and Civil Engineering, Saint Petersburg, Russia \\ ${ }^{2}$ Kyrgyz-Russian Slavic University named after the first President of the Russian Federation B.N. Yeltsin, Bishkek, \\ Kyrgyz Republic \\ *Corresponding author.Email: asaul@yandex.ru
}

\begin{abstract}
Demographic decline and zoning restrictions are in an endogenous equilibrium with one another. That's why the research on how to amplify the positive feedback loops between those two areas is crucial. This is an econometric study of correlation between construction and demographics, with the subject matter being the integration between the EAEU and the Russian Federation. The result of our analysis is specific recommendations for boosting the demographics and construction in Russia and EAEU.
\end{abstract}

Keywords: population, housing demography, housing, construction, correlation, approximation, rate of construction, rate of demographic growth.

\section{INTRODUCTION}

Russia is at a major turning point in its technological and economic restructuring [1]. On 25 September, the United Nations General Assembly unanimously adopted the Resolution 70/1, Transforming our World: the 2030 Agenda for Sustainable Development. This historic document lays out the 17 Sustainable Development Goals, which aim to mobilize global efforts to end poverty, foster peace, safeguard the rights and dignity of all people, and protect the planet.

However, there's no specific objectives in UN's resolution.

It's a common idea that sustainable development is a new trend, but that's just not the case. Just recently the Russian government worked on the sustainable development of human potential program [3-8] (from 2000 to 2015 , with 8 objectives). When that program ended, the UN created a new program, based on that old one, but with 7 additional objectives.

The research of scientific collective called «Methodological problems of the economic effectiveness of regional construction clusters as a self-ordering system» was always focused on sustainability [9-10]. Realization of concepts on increasing the quality-of-life index [11-13], as well as innovation in construction of housing [14-16] is our forte. Institutional design of land use [17-20] and unification of organizational frameworks [21-24] are key. Based on the analysis of the rate of new construction $[25,26]$, we outlined three scenarios to keep in mind if you're concerned about the future of construction, demographics and quality-of-life in Russia [27]. The degree of interdependency of the aforementioned is specifically defined in this article [2829]. It's a scientific consensus at this point that the role of housing construction in demographics had been extremely undervalued until recently [30]. This article is a cornerstone for the future unified demographics-andconstruction public policy of Russian Federation.

Applicability. In EAEU and Russia construction is relatively booming, while demographics are in decline, even despite the governmental monetary stimulus for young parents. That's quite a paradox. The uneven rhythm between the two is the main challenge of the Russian growth policy, both in terms of practice and theory. Turning a disproportionate relationship into a 
proportionate one is the key to achieving sustainable growth.

Research objective: Defining the interdependency between the dynamics of growth in construction and population in EAEU and Russia.

\section{Sub-objectives:}

- define the degree of interdependency between renting and the annual average of population.

- make a model of the index of new construction and the index of correlation degree;

- formulate recommendations for the unified demographics-and-construction public policy of Russian Federation.

Object of research: Public amenities and sustainable development of society.

Subject of research: dynamics of growth in construction and population in EAEU and Russia.

Scientific novelty: the degree of interdependency is specifically outlined. The potential of further research in this area is proven.

\section{MATERIALS AND METHODS}

Correlational analysis, conventional econometrics.

\section{RESULTS AND DISCUSSION}

Based on [31], we have to outline the cycle of construction in Russia and EAEU. The trend line of new construction is described by the function $\mathrm{y}=-0,1351 \mathrm{x}^{2}$ $+5,2246 \mathrm{x}+51,435$ with falsifiability of $87 \%$ and $\mathrm{R}^{2}=$

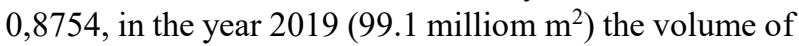
new construction is 5 million $\mathrm{m}^{2}$ higher compared to the year 2018, when it was $\left(93.8\right.$ million $\left.\mathrm{m}^{2}\right)$. Because of that, the slow rate of volume increase in construction is expected in EAEU and Russia. By looking at the difference between the rates of growth in population and construction, we will forecast the time of getting to the deficit in housing.

As outlined in [32], in the year $2019(105,8 \%)$ the rate of renting in Russia and EAEU increased by $8 \%$ compared to the year $2018(97,8 \%)$. The pique of population growth was in the year $2015(101,7 \%)$, after $(100,4 \%)$ in 2014. [33].

Predictable waves of boom and bust exist in the cycle of demographics and population growth. Particularly huge disparities happen from 2005 to 2007 and from 2013 to 2014 . In 2019 году an increase in renting is ahead of the increase in population, which is a good sign for the forecasted increase in housing affordability. However, the slow population growth creates an illusion that the ratio between population and construction growth is good. The slow population growth is the main reason why the rate of increase in housing affordability seems good. The construction itself isn't getting sufficiently more robust as an industry. Worldwide, it's a common problem that a decrease in mortality isn't yet accompanied by a sufficient decrease in morbidity, thus leading to a less productive economy, additionally plagued with economic hurdles to a demographic increase, and, in turn, this all creates a negative feedback loop. This situation leads to an increase in living space per person (a decrease in population density). In Russian Federation, the objective is that there ought to be no less than $18 \mathrm{~m}^{2}$ of living space per person. The standard numbers are $33 \mathrm{~m}^{2}$ per one person, $42 \mathrm{~m}^{2}$ for a family of two, and $18 \mathrm{~m}^{2}$ per every family member once the number of family members is bigger than 3. Currently, a decrease in population leads to a decrease in construction, which creates a negative feedback loop because a proficit in construction leads to an increase in population, while decrease in construction leads to a significant further decrease in population.

As we look at the dynamics between demographics and construction in Russia, (Drawing 1. The diagram is made according to the EAEU statistics from 2005 to 2019 (EAEU statistics: http://www.eurasiancommission.org/r u/act/integr_i_makroec/dep_stat/econstat/Pages/populati on.aspx.)), we see a general similarity between Russia and other EAEU members. However, there's some important differences: First of all, the periods when the new housing gets its first owners and tenants are particularly stark. The trajectory is upward. The years of boom were 2007-2008, with 61,2 and 64,1 million $\mathrm{m}^{2}$ of housing. The second boom was 2014-2015, with 84,2 and 85,3 million $\mathrm{m}^{2}$ of new housing. From 2015 to 2019, it's trending downward: yearly median is 75,7 million $\mathrm{m}^{2}$. We forecast an upwards trend in 2020.

When it comes to the population growth, the dynamics are less positive, though overall there's some growth and stabilization from 2015 to 2019. However, we forecast a decrease here. Russia has Correl $=0,728$, while EAEU has Correl $=0,853$. Kazakhstan and Kyrgyzstan, the EAEU members, have such a high demographic potential that together they raise the nonweighted arithmetic mean value way up.

There were years of new housing boom with the size of $20 \%$ increase compared to the previous year: in 2007 and in 2014. However, not even once in 15 years the rate of population increase had been higher than $2 \%$ compared to the previous year. For the first and second child, the monetary stimulus for parenting that the Russian government provides had been proven as sufficient. However, that stops at the third child. Why? Because of the housing problem. Housing assistance is absolutely necessary if the government wants Russians to have 3 or more kids. Housing assistance should exist both in a sense of stimulating the supply of housing and the direct monetary assistance to parents. 


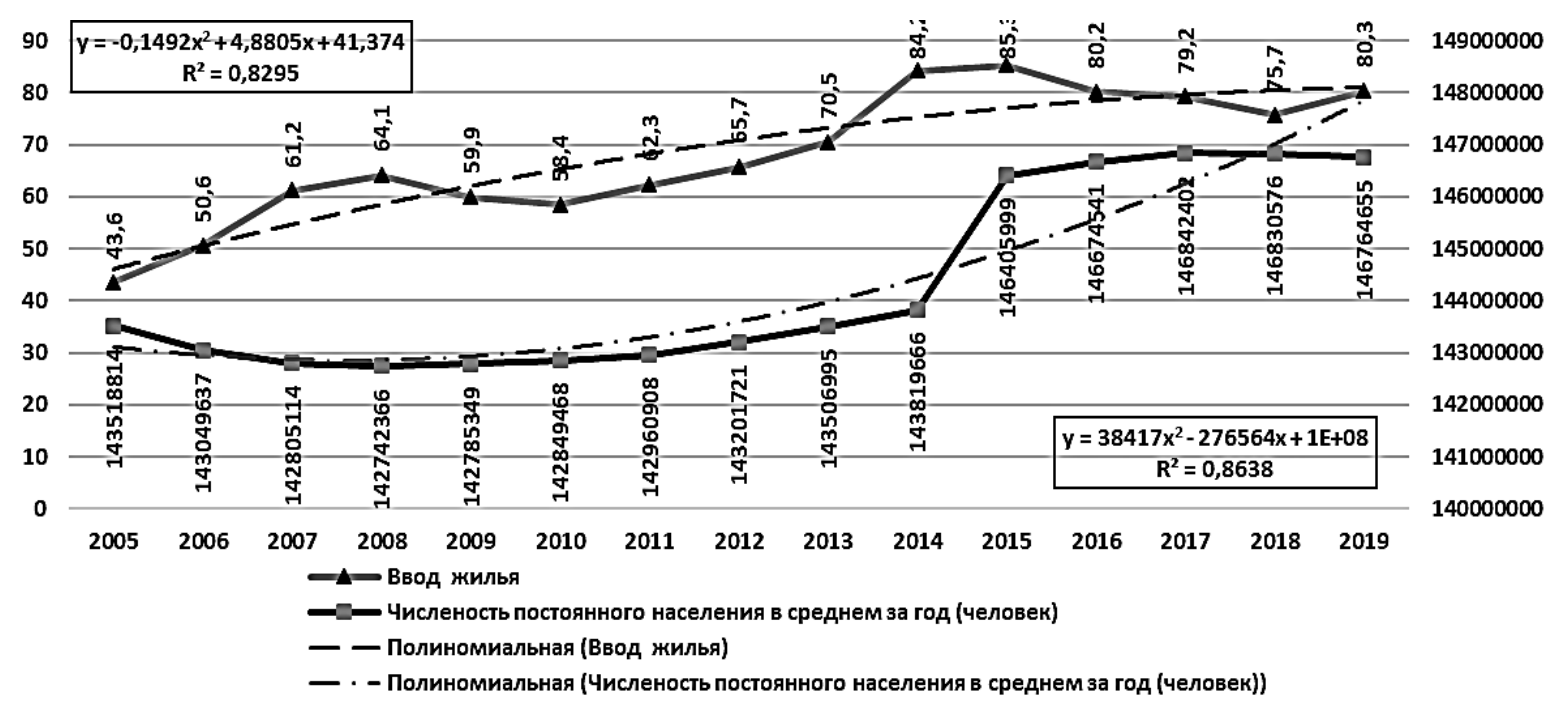

Figure 1 New construction (million $\mathrm{m}^{2}$ ) и the number of annual average population (persons) in Russia, where: ввод жилья - housing commissioning, Численность постоянного населения в среднем за год (человек) Average resident population per year (people), полиномиальная (ввод жилья) - polynomial (housing input), полиномиальная (Численность постоянного населения в среднем за год (человек)) - polynomial (Number of resident population on average per year (people)).

\section{CONCLUSION}

We defined the degree of interdependency between renting and the annual average of population. Developed a model of the index of new construction and the index of correlation degree. Formulate recommendations for the unified demographics-and-construction public policy of Russian Federation.

\section{ACKNOWLEDGMENTS}

The authors of this article are sincerely grateful to the faculty members and organizers of the journal club called «Methodological problems of the economic effectiveness of regional construction clusters as a self-ordering system».

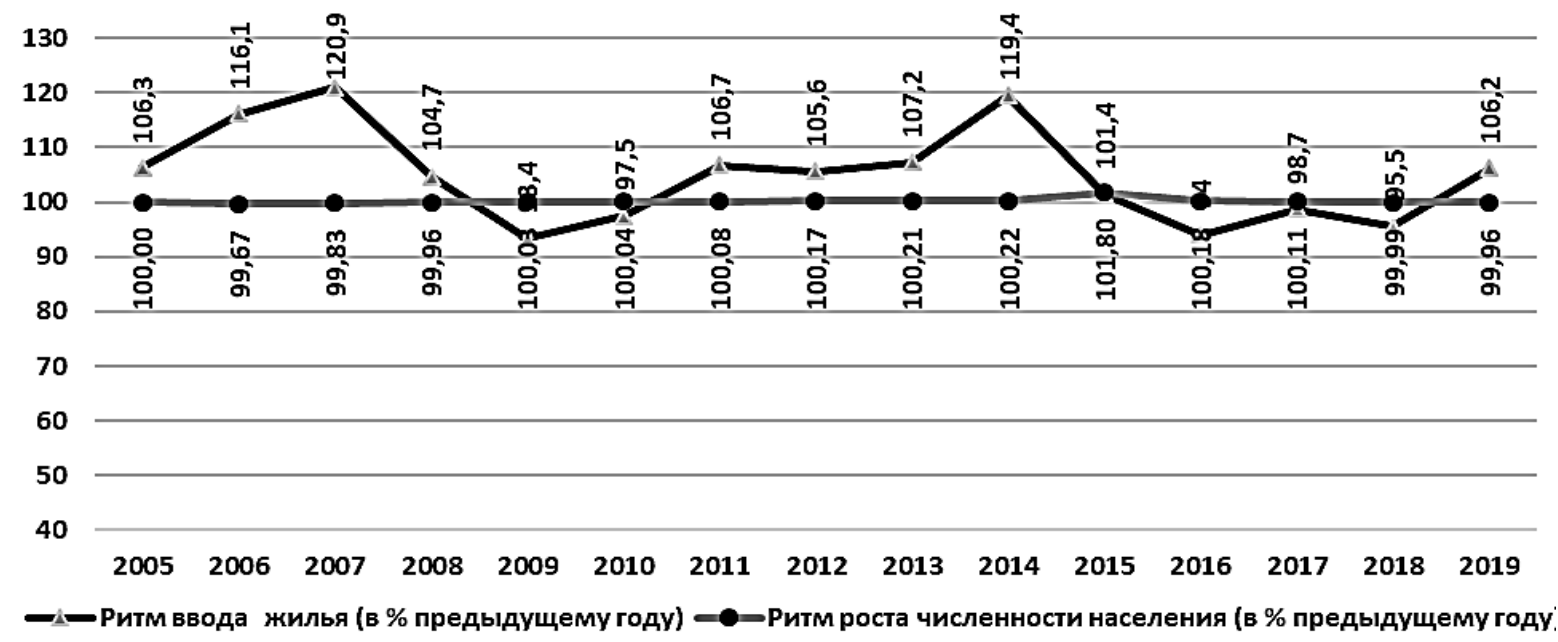

Figure 2. Rhythm of the introduction of new construction and the increase of population (in \% relative to the previous year). According to Rosstat, from 2005 to 2019, where: ритм ввода жилья (в \% предыдущему году) the rhythm of housing commissioning (in\% of the previous year), ритм роста численности населения (в \% предыдущему году) - population growth rate (in \% of the previous year) 


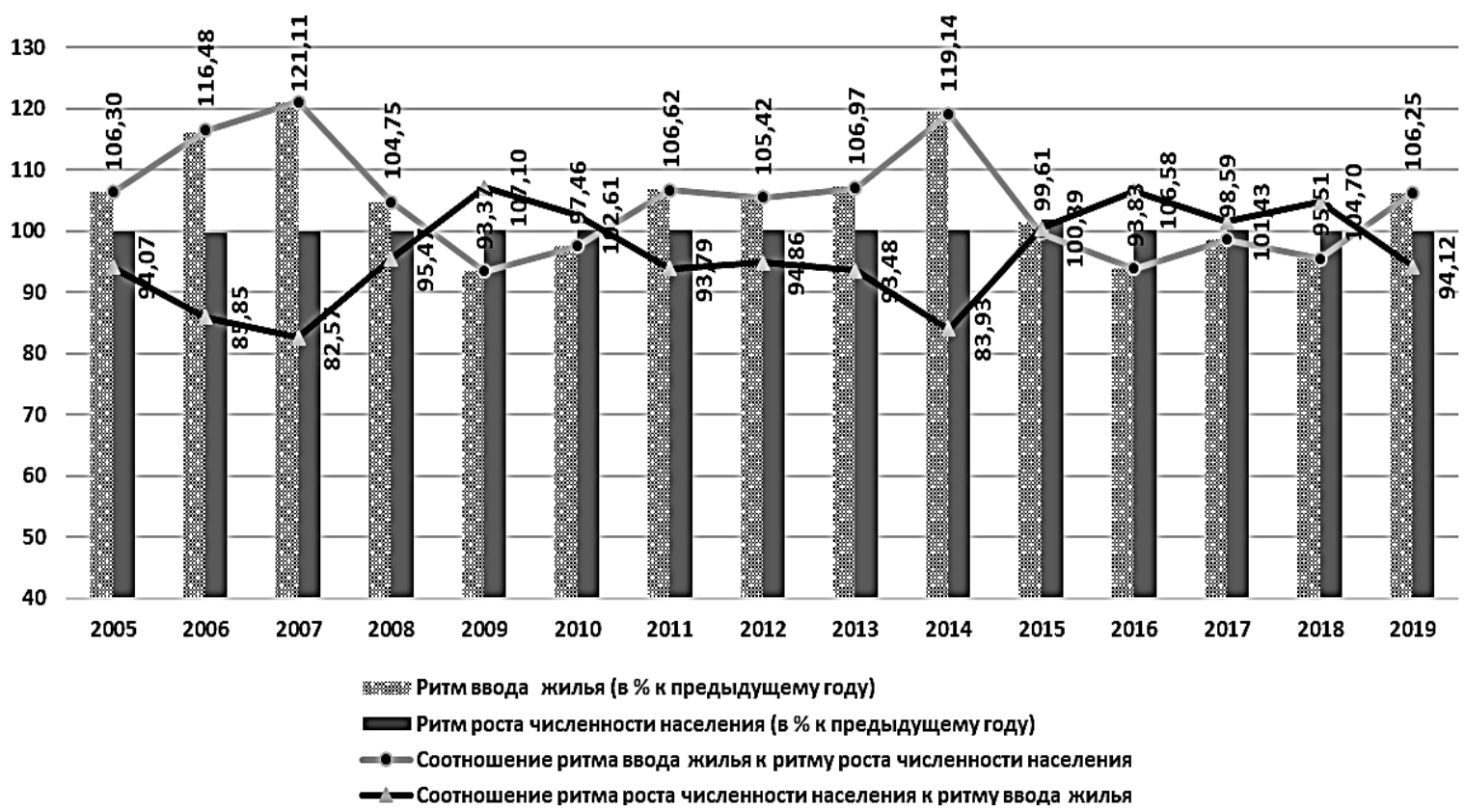

Figure 3. Endogeneity between construction and demographics. According to Rosstat, from 2005 to 2019, where: ритм ввода жилья (в \% предыдущему году) - the rhythm of housing commissioning (in \% of the previous year), ритм роста численности населения (в \% предыдущему году) - population growth rate (in\% of the previous year), соотношение ритма ввода жилья к ритму роста численности населения - the ratio of the rhythm of housing commissioning to the rhythm of population growth, соотношение ритма роста численности населения к ритму ввода жилья - the ratio of the rhythm of housing commissioning to the rhythm of population growth

\section{REFERENCES}

[1] M.A. Asaul, The strategy of the advanced development of the Russian economy as a basis for a radical change in the economic course of Russia. The value of the results of research activities lies in reflecting the objective needs of the domestic economy, In: Mat. reg. XXI scientific. conf. from int. participation. ANO IPEV, 2020, pp. 309-313.

[2] Achieving the Sustainable Development Goals in the Region of the Eurasian Economic Union. Statistical abstract. Eurasian Economic Commission, 2019, p. 95.

[3] M.P. Voinarenko, S. Ya. Knyazev, T.G. Rzayeva, Production and economic potential and business activity of business entities. ANO IPEV, 2011. DOI: https://doi.org/10.23682/18209.

[4] A. N. Asaul, V. P. Grakhov, O. S. Koval, Ye. I. Rybnov, Theory and practice of developing the adoption and implementation of management decisions in entrepreneurship. ANO IPEV, 2014, p. 304. DOI: https://doi.org/10.23682/38597.

[5] A. N. Asaul, D.A. Zavarin, S.N. Ivanov, The main obstacles to the development of innovative activity in the investment and construction sphere. Fundamental research 4 (2015) pp. 180-184.
[6] Kh.S. Abaev, Yu.A. Molchanov, Theory and practice of management and development of property complexes. ANO IPEV, 2006. DOI: https://doi.org/10.23682/18218.

[7] A.N. Asaul, Development of civil society institutions in the investment and construction sphere. Bulletin of civil engineers 3(12) (2007) pp. 68-72.

[8] A.N. Asaul, I.V. Denisova, Y.L. Matveev, V.I. Frolov, Management of a company based on the development of strategies for its development. Humanistics, 2003, p. 168.

[9] A.V. Gorkovenko, G.F. Shcherbina, A.A. Voznyuk, Analysis of factors affecting the financial stability of construction enterprises. Bulletin of the Volga State University of Service 1(15) (2011) pp. 138143.

[10] G.F. Shcherbina, System principles and properties in the activities of a vertically integrated construction holding. Issues of Economics and Law. 45 (2012) pp. 226-234.

[11] E. Pesotskaya, L. Selyutina, E. Trushkovskaya, Creation of integrated interaction monitoring in the construction companies management, In: IOP Conference Series: Materials Science and 
Engineering. Ser. "International Conference on Construction, Architecture and Technosphere Safety. ICCATS, 2020, p. 022082. DOI: https://doi.org/10.1088/1757-899X/962/2/022082.

[12] L.G. Selyutina, E.V. Pesotskaya, E.D. Trushkovskaya, Analysis of approaches to the implementation of programs for the urban complexes reconstruction in Russia, In: IOP Conference Series: Materials Science and Engineering. International Science and Technology Conference "FarEastCon 2019", 2020, p. 032044. DOI: https://doi.org/10.1088/1757899X/753/3/032 044 .

[13] A.N. Asaul, Implementation of the national project in the field of housing construction. Scientific works of the Free Economic Society of Russia 69 (2006) pp. 14-19.

[14] E.D. Trushkovskaya, S.V. Kondratyev, Manageme nt of competitiveness in the field of housing and communal services on the example of HOA. Economics and Entrepreneurship 6(83) (2017), pp. 934-936.

[15] E.D. Trushkovskaya, Kh.A. Magamadov, Formatio $\mathrm{n}$ of conditions for the implementation of projects of integrated development of territories. Bulletin of civil engineers 5(40) (2013) pp. 257-260.

[16] E. D. Trushkovskaya, Formation of an effective management model for the reconstruction of the housing stock of St. Petersburg. Management of economic systems: electronic scientific journal 9 (33) (2011) p. 29.

[17] A.N. Asaul, A.V. Lobanov, Institutional units in the regional investment and construction complex: criteria and methods of allocation. Economy of Ukraine 11 (2010) p. 47.

[18] A.N. Asaul, Development of civil society institutions in the investment and construction sector. Bulletin of civil engineers 3(12) (2007) pp. 68-72.

[19] A.N. Asaul, A.V. Lobanov, A promising model for the development of regional investment and construction complexes. Economy of Ukraine 7 (2011) p. 72.

[20] A.N. Asaul, Prospects for the cluster organization of entrepreneurial activity in Russia. Bulletin of civil engineers 3(32) (2012) pp. 223-236.

[21] E.I. Rybnov, M.A. Asaul, Using the tools of the theory of catastrophes for modeling the sustainability of entrepreneurial structures. Bulletin of civil engineers 3(24) (2010) pp. 141-145.
[22] M.A. Asaul, Management of the sustainability of business structures. ANO IPEV, 2008, p. 285. DOI: https://doi.org/Project 302 10.17513/.

[23] M.A. Asaul, Maintaining the stability of the construction organization. Economic revival of Russia 4(18) (2008) pp. 53-59.

[24] M.A. Asaul, Ensuring the sustainability of entrepreneurial structures in the investment and construction sector, Dissertation for the degree of Doctor of Economics, GOUVPO "St. Petersburg State University of Architecture and Civil Engineering". St. Petersburg, 2009, p. 349.

[25] J. Levin, G. Shcherbina, E. Trushkovskaya, Proactive mechanisms for response to risks of business entities in investment and construction activities, In: E3S Web of Conferences 2nd International Scientific Conference and Civil Engineering (STCCE - 2021), 2021, p. 05007. DOI: https://doi.org/10.1051/e3sconf/202127405007.

[26] A. Yu. Levin, A.M. Platonov, Energy supply of isolated territories in the context of attracting investment and developing the region's economy. The economy of the region 16(3) (2020) p. 884895. DOI: https://doi.org/10.17059/ekon.reg.2020-3-16.

[27] P. B. Lyulin, N. V. Chepachenko, Trends of housing construction in Russia and medium-term forecast. Problems of forecasting 3(174) (2019) pp. 111-117. DOI: https://doi.org/10.1134S1075700719030055.

[28] A.B. Assylbayev , K.N. Niiazalieva, Analysis of the correlation between the housing sector and the natural process of population movement. Bulletin of the University (Russian-Tajik (Slavic) University). 2(62) (2018) pp. 146-159.

[29] A.B. Assylbayev , K.N. Niiazalieva, Formation of housing demography in the general theory of population. Bulletin of the Tajik National University 3 (2018) pp. 91-96.

[30] A.B. Assylbayev, K.N. Niiazalieva, The relationship of demographic processes with the housing conditions of citizens in the Kyrgyz Republic. Bulletin of the Kyrgyz-Russian Slavic University 18(11) (2018) pp. 14-22.

[31] A. Assylbayev, Study of older households with their living conditions, Process Management and Scientific Developments. Part 1, 2021 pp. 8-17. DOI: https://doi.org/10.34660/INF.2021.40.81.001.

[32] A.B. Assylbayev, Issues of the relationship between the processes of housing provision and changes in the age structure of the population in the EAEU countries. Demographic aging of the population: threats and new realities, In: Materials int. scientific- 
practical. Conf., X All-Russian Science Festival NAUKA 0+, "Econ-Inform", 2020 pp. 13-31.

[33] A B. Assylbayev, K.N. Niiazalieva, Diagnostics of the housing factor in demographic processes as a subject area of housing demography. Technological entrepreneurship and commercialization of innovations in the investment and construction sector Part 1, In: Int. XX scientific. Conf., St. Petersburg, 2018, pp. 49-68. 